\title{
In vitro Phosphate Solubilization by Sugarcane (Saccharum officinarum) Rhizosphere Bacteria
}

\author{
Ramandeep Kaur ${ }^{1}$ and Chayanika Putatunda ${ }^{1,2^{*}}$ \\ ${ }^{1}$ School of biotechnology and Biosciences, Lovely Professional University, Jalandhar - Delhi \\ G.T. Road, Phagwara, Punjab-144411, India \\ ${ }^{2}$ Department of Microbiology, DAV University, Village Sarmastpur, Jalandhar - Pathankot \\ National Highway, NH 44, Jalandhar, Punjab-144012, India \\ *Corresponding author
}

A B S T R A C T

\begin{tabular}{|l|}
\hline K e y w o r d s \\
$\begin{array}{l}\text { Phosphate solubilization, } \\
\text { bacteria, rhizosphere, } \\
\text { sugarcane, biofertilizer }\end{array}$ \\
\hline Article Info \\
\hline $\begin{array}{l}\text { Accepted: } \\
\text { 18 May } 2018 \\
\text { Available Online: } \\
\text { 10 June } 2018\end{array}$ \\
\hline
\end{tabular}

\section{Introduction}

Sugarcane, one of very important cash crops, is cultivated across the globe especially in the tropical and sub-tropical regions. The sugar industries rely on sugarcane as the major source of raw material. As per FAO (2015), 1800 million tonnes of sugarcane is produced annually at the world level. Worldwide, India ranks number two in sugarcane production after Brazil, which produces the maximum amount of sugarcane. However, the production depends on many agronomic factors including the availability of various plant nutrients. Phosphorus is an essential nutrient and forms an inseparable component of various crucial biomolecules like phospholipids, nucleic acids, ATP etc and hence is an integral part of the metabolism. Sugarcane cultivation requires $15-20 \mathrm{~kg}$ phosphorus/100t of cane (http://www.yara. in/crop-nutrition/crops /sugarcane/key-facts/ nutritional-summary/). Insufficient amount of available phosphorus can severely impair the growth and productivity of plants (Plénet et al., 2000a, Plénet et al., 2009b; Prejambada et al., 2009; Victoria et al., 2009). However, most of the soils do not have sufficient amount of phosphorus so the farmers apply chemical fertilizers which in turn adds financial burden 
on the farmers apart from adversely impacting the environment (Maheshwar and Sathiyavani, 2012). Moreover a very less amount of the added fertilizer is actually utilized by the plants and as much as 75 to $90 \%$ gets precipitated by iron, aluminum and calcium complexes present in soils and thus become insoluble and unavailable to plants (Turan et al., 2006).

Phosphate solubilizing microorganisms can be a possible solution to these problems. Whiltelaw (2000) have described strains from bacterial genera Pseudomonas, Bacillus, Rhizobium and Enterobacter along with the fungi like Penicillium and Aspergillus as the most powerful phosphate solubilizers. Some of the bacteria like Azospirillum, Burkholderia, Alcaligenes, Acinetobacter, Flavobacterium etc. have also been found to possess good phosphate solubilizing activity (Rodríguez and Fraga, 1999).These microorganisms use a variety of mechanisms like secretion of chelating agents, acidification by producing an array of organic and inorganic acids and thus convert the insoluble phosphate into bioavailable soluble form (Kundu et al., 2009; Delvasto et al., 2008)

Therefore, Phosphate solubilizing microorganisms can be used as inoculants to increase crop yield by solubilizing insoluble $\mathrm{P}$ in soils. Many of these microbes also possess many additional plant growth promoting attributes like nitrogen fixation, production of phytohormones, acting as antagonists towards phytopathogens. There are many reports of isolation of various phosphate solubilizing bacteria from rhizospheres of a variety of plants like rice (Islam et al., 2006), groundnut (Maheshwar and Sathiyavani, 2012; Kuntia et al., 2014), black peper (Ramachandran et al., 2007), wheat (Thakur and Putatunda, 2017) Trigonella (Neelam and Meenu, 2003), sunflower (Patel and Parmar, 2013). Sundara et al., (2002) studied the effect of applying the phosphate solubilizing bacterial culture of $B$. megatherium var phosphaticum to sugarcane and observed enhancement of number of tillers, increase in stalk population and stalk weight, ultimately resulting in increase in sugarcane yield. These researchers also reported that the application of PSB along with phosphate fertilizer resulted in 25\% decrease in the required dosage of phosphorus.

\section{Materials and Methods}

\section{Isolation of Phosphate solubilizing Bacteria}

A total of four soil samples were collected from rhizosphere of sugarcane. Two samples were collected from the sugarcane fields of Una (Himachal Pradesh, India) at the distance of $5 \mathrm{Km}$ from each other, and two samples were obtained from Bathinda (Punjab, India) separated by a distance of $4 \mathrm{Km}$. The bacterial isolates were obtained by spreading the appropriately diluted soil samples on Pikovskaya's medium plates (Pikovskaya, 1948) containing insoluble phosphorus in the form of tricalcium phosphate. The bacterial isolates obtained were purified by re-streaking and stored in refrigerated conditions at $4^{\circ} \mathrm{C}$ on slants till further use.

\section{Screening of bacterial isolates}

All the purified phosphate solubilising bacterial strains obtained were spotted and incubated over Pikovskaya's media and zone of hydrolysis and colony diameter were measured. The phosphate solubilization efficiency (PSE) was calculated on the basis of colony size and zone of phosphate solubilization as per the given formula given by Kundu et al., (2009). All the bacterial isolates were further subjected to secondary screening by evaluation of solubilisation of insoluble phosphorus into soluble form in Pikovsakya's broth under agitated conditions at $37{ }^{\circ} \mathrm{C}$ and incubation period of 72 hours by 
the method described by Narveer et al., (2014). The quantity of solubilized phosphorus in the supernatant was assessed by John's (1970) method. The best two isolates were used for subsequent experiments.

\section{Optimization of conditions}

Various cultural conditions like incubation period, $\mathrm{pH}$, carbon source and nitrogen source were varied one factor at a time to analyze their impact on the phosphate solubilisation efficiency of the selected isolates.

\section{Partial Characterization of selected isolates}

Selected strains were characterized for various morphological and biochemical characteristics according to Bergey's manual of systematic bacteriology.

\section{Results and Discussion}

In the present investigation, a total of twenty two isolates were obtained from all the four soil samples. From the sample taken from Bathinda (Punjab), seven isolates were obtained while the other sample from Bathinda (Punjab) yielded five isolates. From the two sugarcane rhizosphere soil samples collected from Una (Himachal Pradesh), five bacterial isolates each were obtained. Lamizadeh et al., (2016) reported isolation of 40 phosphate solubilizing bacterial isolates from sugarcane plants growing in saline and non-saline conditions and identified the most promising isolates to be members of the genera Enterobacter, Paenibacillus and Pseudomonas. Awais et al., (2017) have isolated fifteen phosphate solubilizing bacterial isolates from rhizosphere of rice and sugarcane which were also found to be capable of Indole acetic acid production. Some of these isolates also possessed antifungal activity.

All the twenty two isolates were subjected to primary screening by plate assay method and the phosphate solubilization efficiency (PSE\%) was calculated. Maximum PSE ranging between 150 to $200 \%$ was shown by isolates like SCRU3, SCRU4 and SCRU5 while in case of SARB3 only 9\% PSE was observed. Also, in case of isolates like SARB1, SARB2 no zone of phosphate solubilization was observed. The primary screening was followed by secondary screening under liquid culture conditions as many workers have questioned the reliability of plate assay method for screening of phosphate solubilizing bacteria since some of the isolates which do not show clear zone formation may be having the ability to solubilize a good amount of phosphorous in liquid medium (Johnston, 1952; Yadav and Dadarwal, 1997; Balamurgan, 2010; Kundu et al., 2009; Saini et al., 2015). The isolates SCRU2 and SDRB4 showed the best results $(14.4 \mu \mathrm{g} / \mathrm{ml}$ and $13.8 \mu \mathrm{g} / \mathrm{ml}$ respectively) in terms of phosphate solubilization during secondary screening and hence were selected for further experimentation.

The phosphate solubilization efficiency is impacted by many cultural conditions like incubation period, $\mathrm{pH}$, nutrients etc. So, in order to ascertain the effect of incubation period, the selected isolates were incubated for different time intervals. It was observed that both the isolates, the amount of phosphate solubilization increased with increase of incubation period till 96 hours.

On further incubation, there was very slight enhancement of activity (Fig-1). Similar results have also been obtained by Narveer et al., (2014), Thakur and Putatunda (2018). However, many workers have reported much longer incubation period of 10 days or more to be suitable for microbial phosphate solubilization (Sahu et al., 2007; Sridevi \& Mallaiah, 2009). 
Fig.1 Effect of incubation period on the phosphate solubilization activity $(\mu \mathrm{g} / \mathrm{ml})$ of the selected isolates SCRU2 and SDRB4

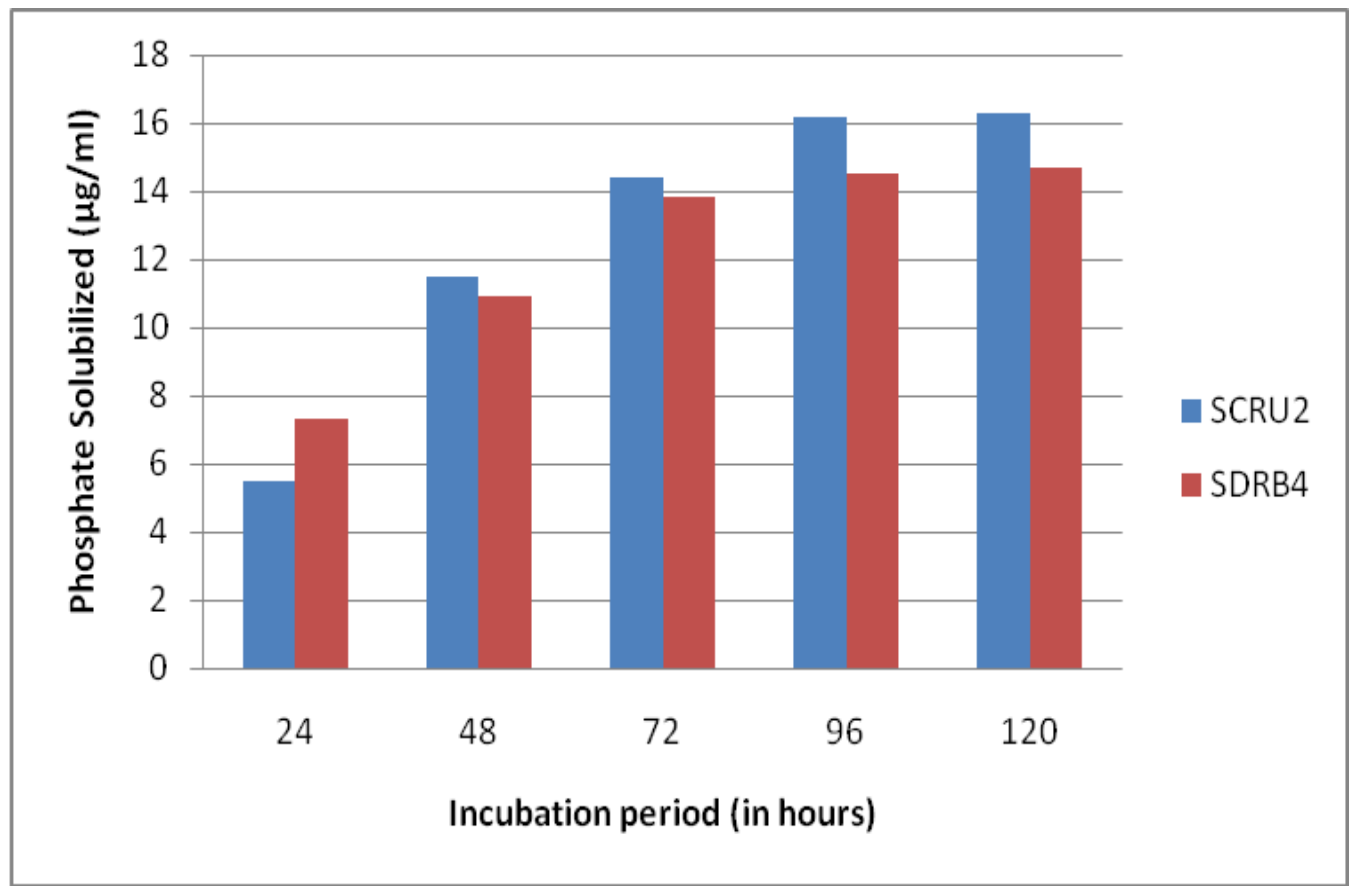

Fig.2 Effect of $\mathrm{pH}$ on the phosphate solubilization activity $(\mu \mathrm{g} / \mathrm{ml})$ of the selected isolates SCRU2 and SDRB4

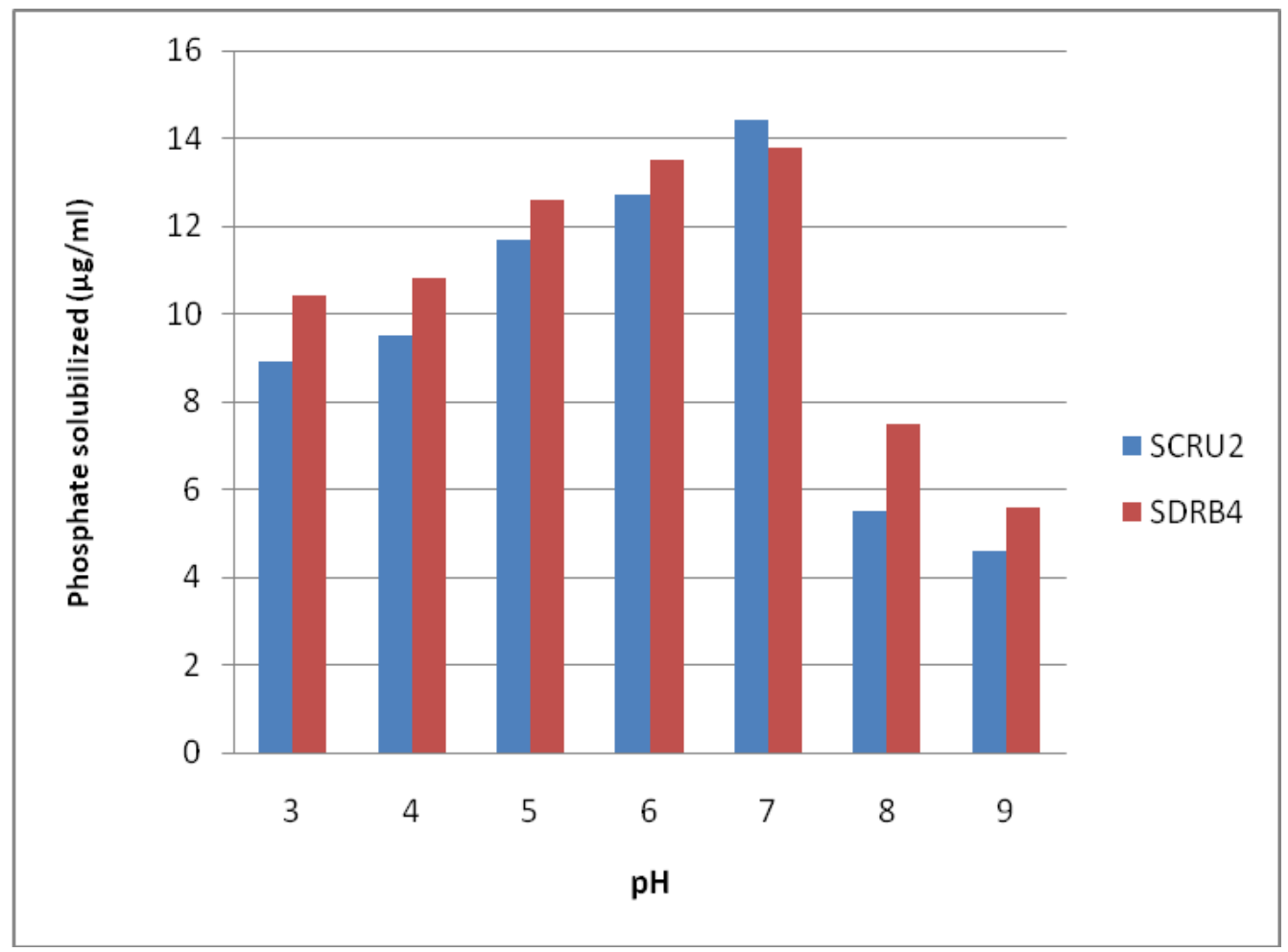


Fig.3 Effect of carbon source on the phosphate solubilization activity $(\mu \mathrm{g} / \mathrm{ml})$ of the selected isolates SCRU2 and SDRB4

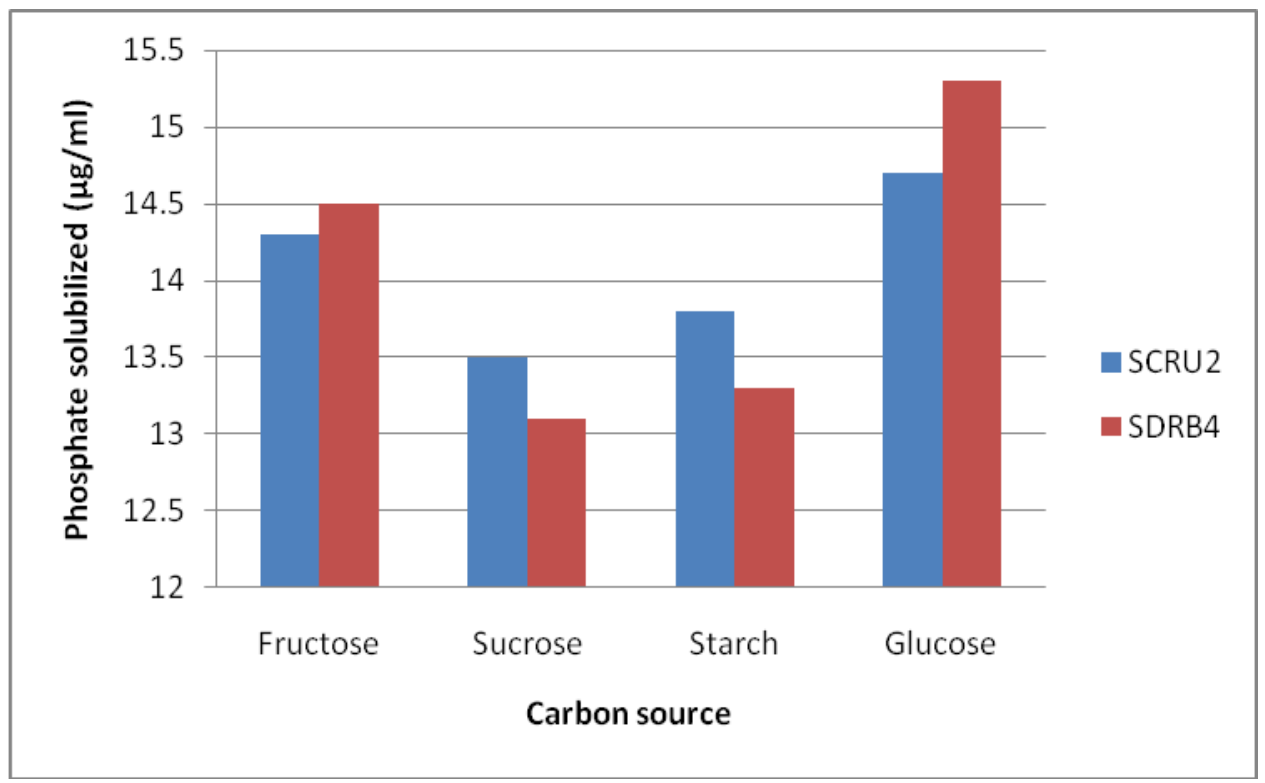

Fig.4 Effect of nitrogen source on the phosphate solubilization activity $(\mu \mathrm{g} / \mathrm{ml})$ of the selected isolates SCRU2 and SDRB4

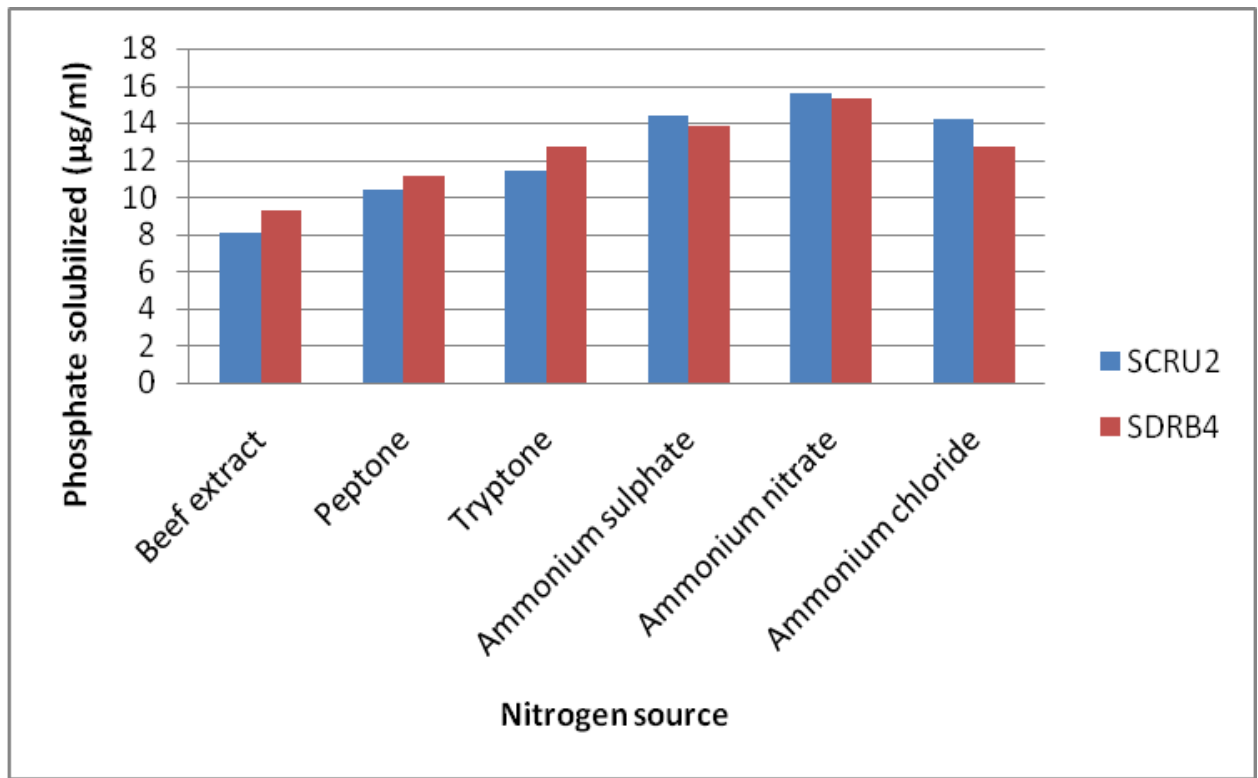

In case of $\mathrm{pH}$, the maximum solubilization was observed in case of $\mathrm{pH} 7.0$ in both the isolates, although comparable values were observed in pH 6 and 5 also (Fig 2). However, on going beyond 5, i.e. $\mathrm{pH} 4.0$ and 3.0 on the acidic side and also in the alkaline $\mathrm{pH}$ of 8.0 and 9.0, a conspicuous drop in the phosphate solubilization was observed in case of both the isolates. The neutral $\mathrm{pH}$ has been found to be suitable for microbial phosphate solubilization by many workers (Chen et al., 2005; Xiang et al., 2011; Yu et al., 2011). 
The nutrients like carbon source and nitrogen source have also been found to be crucial for the phosphate solubilizing activity of microbes. In the present investigation, both the isolates i.e. SCRU2 and SDRB4 were found to exhibit maximum phosphate solubilization with glucose followed by fructose (Fig 3). Lesser activity was observed in case of the complex carbon source like starch and sucrose (a disaccharide). This is in agreement with reports by many workers who have observed glucose to be the preferred carbon source for phosphate solubilizing microbes (Pandey et al., 2006; Patel et al., 2008; Balamurugan et al., 2010). This could be because of the reason that glucose being the simplest and readily usable carbon source yields better microbial activity. In order to assess the effect of nitrogen, both organic and inorganic forms of nitrogen were tested. It was observed that over all the inorganic sources resulted in better phosphate solubilization as compared to the organic ones.

In case of SCRU2 as well as SDRB4, the maximum phosphate solubilization was observed in case of ammonium nitrate. Ammonium salts have been reported by several workers to be favored by the phosphate solubilizing microbes (Illmer and Schinner, 1992; Lapeyrie et al., 1991; Kumari and Gupta 2013). On growing the isolates in optimized conditions, the phosphate solubilization activity of SCRU2 isolate increased to $18.7 \mu \mathrm{g} / \mathrm{ml}$ of phosphorous and that of the isolate SDRB4 increased to 19.6 $\mu \mathrm{g} / \mathrm{ml}$ of phosphorous.

Both the isolates were characterized on the basis of some morphological and biochemical characteristics. The bacterial isolate SDRB4 was found to be gram negative, rod shaped, motile, no spore formation, Indole negative, methyl red negative, voges-proskauer negative, urease negative, citrate positive, glucose and lactose non fermenting, Catalase positive. So, anything cannot be said conclusively about its identity but it does resemble Pseudomonas. On the other hand, the isolate SCRU2 was gram positive, acid fast negative, rod shaped, spore forming, methyl red positive, voges-proskauer negative, Indole negative, urease positive, citrate positive, and catalase positive. So, it appears that this isolate is a member of genus Bacillus.

The present investigation was carried out with the aim of isolation and characterization of Phosphate solubilizing bacteria from rhizosphere soil of sugarcane plant. A total of 22 bacterial isolates were obtained, out of which the two showing maximum phosphate solubilization (SCRU2 and SDRB4) were selected for further studies. These isolates showed maximum phosphate solubilization with glucose as the carbon source, ammonium nitrate as the nitrogen source, $\mathrm{pH} 7$ and incubation period of 96 hours. So, more research is required to analyze the in vivo phosphate solubilization efficiency of these isolates in order to ascertain their possible application as biofertilizers.

\section{References}

Awais, M., Tariq, M., Ali, A., Ali, Q., Khan, A., Idrees, B.T., Nasir, A. and Husnain, T. 2017. Isolation, characterization and inter-relationship of phosphate solubilizing bacteria from the rhizosphere of sugarcane and rice. Biocat. Agric. Biotechnol. 11: 312-321.

Balamurgan, A., Princy, T., Vidhyapallavi, R., Nepolean, P., Jayanthi, R. and Premkumar, R. 2010. Isolation and characterization of phosphate solubilizing bacteria in Tea. J. Biosci. 1:285-293.

Chen, Y. P., Rekha, P.D, Arunshen, A.B., Lai, W.A. and Young, C.C. 2006. Phosphate solubilizing bacteria from subtropical soil and their tricalcium phosphate 
solubilizing abilities. Appl. Soil Ecol. 34:33-41.

Delvasto, P., Valverde, A., Ballester, A., Muñoz, J.A., González, F., Blázquez, M.L., Igual, J.M., and García-Balboa, C. 2008. Diversity and activity of phosphate bioleaching bacteria from a highphosphorus iron ore. Hydrometallurgy. 92: 124-129.

Illmer, P. and Schineer F. 1992. Solubilization of hardly-soluble $\mathrm{AlPO}_{4}^{-}$with solubilizing microorganisms. Soil Bio Biochem. 24: 389-395.

John, M.K. 1970. Colorimetric determination of phosphorus in soil and plant materials with ascorbic acid. Soil Sci. 109: 214 220.

Johnston, H.W. 1952. The solubilization of phosphate: I. The action of various organic compounds on dicalcium and tricalcium phosphate. NZ J. Sci. Technol. 33:436-444.

Kumari, P. P. and Gupta, P. C. 2013. Effect of different carbon and nitrogen sources on solubilization of insoluble inorganic phosphate by psychrotolerant bacterial strains. Bioscan. 8: 1299-1302

Kundu, B.S., Nehra, K., Yadav, R. and Tomar, M. 2009. Biodiversity of phosphate solubilizing bacteria in rhizosphere of chickpea, mustard and wheat grown in different regions of Haryana. Indian $\mathbf{J}$ Microbiol. 49:120-127.

Kuntia, M., Vyas, A. and Putatunda, C. 2014.Isolation and partial characterization of phosphate solubilizing bacteria from groundnut rhizosphere. Inter. J. Trop. Agric. 32:533-538.

Lamizadeh, E, Enayatizamir, N and Motamedi, H. 2016. Isolation and identification of plant growth-promoting rhizobacteria (PGPR) from the rhizosphere of sugarcane in saline and non-saline soil. Int. J. Curr. Microbiol. App. Sci. 5: 10721083.

Lapeyrie, F., Ranger, J. and Vairelles, D. 1991. Phosphate solubilizing activity of ectomycorrhizal fungi in vitro. Can. J. Bot. 69: 342-346.

Maheswar, N., and Sathiyavani, G. 2012. Quantitative analysis of organic acid produced by phosphate solubilizing Bacteria. J. Chem. Pharma. Res. 4:40074011.

Narveer, Vyas, A., Kumar, H. and Putatunda, C. 2014. In vitro phosphate solubilization by Bacillus sp. NPSBS3.2.2 obtained from the cotton plant rhizosphere. Biosci. Biotechnol. Res. Asia. 11:401-406

Neelam, T. and Meenu, S. 2003. Phosphate solubilization exopolysacharide production and indole acetic acid secretion by rhizobactera isolated from Triogella foenumgraceum. Ind. J. Microbiol. 43:37-40

Pandey, A., Trivedi, P., Kumar, B. and Palni, L.S. 2006. Characterization of a phosphate solubilizing and antagonistic strain of Pseudomonas putida (B0) isolated from a sub-alpine location in the Indian central Himalaya. Curr. Microbiol. 53: 102-107.

Patel, D. K., Archana, G. and Kumar, G.N. 2008. Variation in the nature of organic acid secretion and mineral phosphate solubilization by Citrobacter sp. DHRSS in the presence of different sugars. Curr. Microbiol. 56: 168-174.

Patel, D. and Parmar P. 2013 Isolation and screening of phosphate solubilizing bacteria from sunflower rhizosphere. Global.J Biosci. Biotechnol. 2: 438-441.

Pikovskaya, R.I. 1948. Mobilization of phosphorus in soil in connection with vital activity of some microbial species. Microbiologia.17:362-370.

Pl'enet, D., Mollier, A. and Pellerin, S. 2000b. Growth analysis of maize field crops under phosphorus deficiency. II. Radiation-use efficiency, biomass accumulation and yield components. Plant Soil. 224: 259-272

Plénet, D., Etchebest, S., Mollier, A. and Pellerin, S. 2000a. Growth analysis of maize field crops under phosphorus 
deficiency. I. Leaf growth. Plant Soil. 223: 117-130.

Prejambda, I. D., Widada, J., Kibirun, C., and Widianto, D. 2009. Secretion of organic acids by phosphate solubilizing bacteria isolated from oxisols. J. Tanah Trop. 14: $245-25$

Ramachandran, K., Srinivasan, V., Hamza, S. and Anandaraj, M. 2007. Phosphate solubilizing bacteria isolated from the rhizosphere soil and its growth promotion on black pepper (Piper nigrum L.) cutting. Plant Soil Sci. 102: 325 -331.

Rodríguez, H. and Fraga, R. 1999 Phosphate solubilizing bacteria and their role in plant growth promotion. Biotechnol. Adv. 17: 319-339

Sahu, M. K., Sivakumar, K. and Kannan, L. 2007. Phosphate solubilizing actinomycetes in the estuarine environment: an inventory. J. Environ. Biol. 28: 795-798.

Saini, K., Vyas, A., Putatunda, C. 2015. In vitro phosphate solubilization by maize rhizosphere bacteria. Res. J. Pharma. Bio. Chem. Sci. 6: 897-902.

Sridevi, M. and Mallaiah, K.V. 2009. Phosphate solubilization by Rhizobium strains. J. Microbiol. Biotechnol. 49:98-102.

Sundara, B., Natarajan, V. and Hari, K. 2002. Influence of phosphorus solubilizing bacteria on the changes in soil available phosphorus and sugarcane and sugar yields. Fields Crop Res. 77: 43-49

Thakur, I.B. and Putatunda, C. 2017. In vitro phosphate solubilization by Enterobacter spp. isolated from wheat rhizosphere. J. Pure App. Microbiol. 11: 2007-2015.

Turan, M., Ataoglu, N. and Sahin, F. 2006. Evaluation of the capacity of phosphate solubilizing bacteria and fungi on different forms of phosphorus in liquid culture. J Sustainable Agri. 28: 99-108.

Victoria, D. E., Reyes L. L. and Benitez, A. D. L. C. 2009. Use of $16 \mathrm{~S}$ ribosomal gene for characterization of phosphate solubilizing bacteria associated with corn. Rev. Fitotec. Mex. 32: 31-37.

Whitelaw, M. A. 2000. Growth promotion of plants inoculated with phosphate solubilizing fungi. Adv. Agron. 69:99151.

Xiang, W., Liang, H., Liu, S., Luo, F., Tang, J., Li, M., and Che, Z. 2011. Isolation and performance evaluation of halotolerant phosphate solubilizing bacteria from the rhizospheric soils of historic Dagong Brine Well in China. World J. Microbiol. Biotechnol. 27:2629-2637.

Yadav, K.S. and Dadarwal, K.R. 1997. Phosphate solubilization and mobilization through soil microorganisms. In: Biotechnological Approaches in Soil Microorganisms for Sustainable Crop Production (Ed.) K. R. Dadarwal, Scientific publishers, Jodhpur, pp 293308.

Yu, X., Liu, X., Zhu, T. H., Liu, G. H. and Mao, C. 2011. Isolation and characterization of phosphate-solubilizing bacteria from walnut and their effect on growth and phosphorus mobilization. Biol. Fert. Soils. 47:437-446.

\section{How to cite this article:}

Ramandeep Kaur and Chayanika Putatunda. 2018. In vitro Phosphate Solubilization by Sugarcane (Saccharum officinarum) Rhizosphere Bacteria. Int.J.Curr.Microbiol.App.Sci. 7(06): 1557-1564. doi: https://doi.org/10.20546/ijcmas.2018.706.186 